\title{
Blue therapeutic spaces on islands: Coastal landscapes and their impact on the health and wellbeing of people in Malta
}

\author{
Bernadine Satariano \\ University of Malta Junior College, Malta \\ bernadine.satariano@um.edu.mt
}

\begin{abstract}
This paper emphasises that the coastal environment is important for the health and wellbeing of inhabitants living in deprived neighbourhoods in the small island state of Malta. Using qualitative research, it explores how the respondents experience their interaction with the coast and the sea in diverse ways and how this impacts on their health and wellbeing. Making use of qualitative in-depth interviews it analyses the symbolic connections that the respondents have with the sea, the potential that the natural, coastal environment has in enhancing physical activity and mental wellbeing, feelings of embodiment, social interaction and the aspect of temporality. Yet, some nostalgic memories also referred to the aspect of loss and the importance of protection of the natural coastline. This paper acknowledges the deep emotions and strong loving connections that Maltese inhabitants have with the coastal environment and how valuable these spaces are for their health and wellbeing. The fluid, dynamic landforms at sea are greatly important for the health and wellbeing of these individuals and are highly valued therapeutic landscapes within a densely built up environmental island context.
\end{abstract}

Keywords: coasts, health, islands, Malta, therapeutic landscapes, wellbeing

https://doi.org/10.24043/isj.100 • Received April 2019, accepted August 2019

C 2019-Institute of Island Studies, University of Prince Edward Island, Canada.

\section{Introduction}

There is an increased interest in research on the potential effects of blue, aquatic spaces and their promotion for health and wellbeing. The benefits derived from 'green spaces' are widely acknowledged (Maas, Verheij, Groenewegen, de Vries, \& Spreeuwenberg, 2006; Völker \& Kistemann, 2015), but there is a growing interest as well in understanding how the interaction of individuals with 'blue spaces', including inland and coastal aquatic environments, has beneficial effects on health and wellbeing (White, Smith, Humphreys, Pahl, Snelling, Depledge, 2010; Völker \& Kistemann, 2011, 2013; Nichols, 2014). Indeed, several studies have found a relationship between coastal proximity, physical activity and mental health (e.g. Witten, Hiscock, Peace, \& Blakely, 2008). Yet, the concept of therapeutic landscapes and the effect of blue spaces on health and wellbeing have rarely been explored in a small island state context. By drawing upon findings of in-depth qualitative interviews, this paper contributes to filling this gap.

Although the governance of coastal areas mostly focuses on the management and regulation of activities that make use of coastal resources (Ducrotoy \& Furukawa, 2016), this 
study emphasises that it is important to also comprehend the socio-cultural connection that the public has with the coast and the sea and how it impacts on people's health and wellbeing (McKinley \& Acott, 2018). The narratives, attitudes and values of the people living near the coast can provide policy makers with valuable local knowledge that would help in developing a better understanding of the social implications of coastal policy making and implementation. This study enables a better understanding of the diverse experiences, emotions, priorities and interactions of deprived inhabitants living within coastal environments of an island stateinteractions that are likely to promote health and wellbeing, bearing in mind the densely built up environment in which these individuals live. This paper draws upon the reviewed literature in this section and explores the various experiences within a small island state context by looking at how the therapeutic landscape of the coast and the sea contributes to: respondents' symbolic associations; their physical and mental health; the facilitation of socialisation; the impact of temporality of the coast on health and wellbeing; and the fear of loss that islanders feel when changes occur to these therapeutic landscapes.

\section{Defining wellbeing}

WHO (1948) defined health as "a state of complete physical, mental and social well-being and not merely the absence of disease or infirmity." Although 'wellbeing' in itself was not defined, it was the starting point for focusing on the positive attributes of good health. This definition suggests that health and wellbeing involve both individual and social dimensions. However, many writers such as Aggleton (1990) and Dubos (1987) have challenged the WHO definition. Some critics argue that this definition excludes the emotional and spiritual dimensions of health and wellbeing. Others are against the reference to health as a static state or end product. Laverack (2004) explains that researchers should view health as a dynamic relationship of interacting factors, a process, a potential to aspire and to realise aspirations, and a capacity to cope and contribute to society. Moreover, health and wellbeing are experienced in diverse manners, and the experience of wellbeing is not the same for everyone (Reid \& Hunter, 2011). Health and wellbeing in this study are understood as being an outcome due to immediate contact with the sea and/or a process occurring through continuous contact with and interaction near or in the sea.

\section{Historical connection of the Maltese population to coastal areas}

Malta, which is the largest island of the Maltese Archipelago (comprised of Malta, Gozo, and Comino) is located in the centre of the Mediterranean Sea. Due to its strategic position it always had a connection with the sea for both economic and social purposes (Huntingford \& Turner, 2016). Archaeological and mythological evidence from Phoenician (Brody, 1998), Greek (Morton, 2001; Vella, 2002), and Roman (Braudel, 1972) times show how much the coastal areas were used as places for trade, relaxation, restoration of beauty, and pleasure. As recounted in the Acts of the Apostles (XXVIII), St Paul visited Malta due to a shipwreck and brought the Roman Catholic faith to the people of the island. During the Middle Ages and the time of corsairs, the coastal areas of Malta started being avoided due to fear of the pirates (Fontenay, 1988). Yet, with the island's occupation by the Knights of St John, the sea regained its importance and started being regarded as a place of economic and maritime activity, resulting in an increase in population density in coastal localities (Mallia Milanes, 1978). During British rule, apart from the increase in commerce related to the dockyard and ship building industry (Muscat, 2004), 
public bathing and open air recreation started becoming popular. Furthermore, with the advent of affordable air travel, the role of the coast as a place of leisure and entertainment started being valued by both tourists and locals (Zarb, 2004). Due to the increase in foreigners coming to Malta in the 1990s, tourism became one of the major industries on the island, sparking development and the building of hotels along the coast. Indeed, the sea and the coast are frequently included in brochures and advertisements that can lure tourists to Malta (Bossevain, 1996).

\section{Therapeutic landscapes}

The concept of 'therapeutic landscapes' is widely used in geographical research on factors that are important for wellbeing. Some of the earliest work on therapeutic landscapes analysed the role of extraordinary places of physical and spiritual healing such as Bath in England and Lourdes in France (Gesler, 1992, 1996). Researchers extended the idea of therapeutic landscapes by viewing these natural settings as health enablers or promoting environments that are of aesthetic and therapeutic value as everyday spaces (Bell, Foley, Houghton, Maddrell, \& Williams, 2018). In connection with the theory of 'therapeutic landscapes', Tuan (1974) had proposed the term 'topophilia' to explain the affective bonds that individuals may feel towards certain places. When individuals engage with environments that have a reputation for beauty, they give value and importance to such spaces as contributors to their health (Curtis, 2010). Therapeutic landscapes have been described in physiological terms as facilitators that can offer individuals relief from physical symptoms and assist in reducing stress (Gesler, 1992; Kearns \& Collins, 2000). The idea was elaborated further by Gesler (2003, p.1), who interprets a 'therapeutic landscape' as a "healthy place" that is "conducive to physical, mental, spiritual, emotional and social healing." The conceptual framework of 'therapeutic landscapes' incorporates four 'dimensions' of environments that can have 'healing' attributes, as put forward by Gesler: the natural, the built, the social, and the symbolic. Several studies that analyse the concept of therapeutic landscapes also explore how a place can have diverse meanings to different individuals, recognising the relational nature of therapeutic landscapes (Conradson, 2005). Numerous studies (Bell, Phoenix, Lovell, \& Wheeler, 2015; Foley, 2010, 2015; White et al, 2010) find that some individuals benefit greatly from their interaction with the sea, including physical exercise such as walking and running along the coast, swimming, and experiences of embodiment and immersion in the sea, which provide a deep connection with the elements of water (Foley, 2010). Historically, swimming has been recognised as an activity that provides relief from chronic diseases such as rheumatism, arthritis, and skin diseases (Foley, 2010). The therapeutic landscape theory is also connected to the concept of 'sense of place', which is important in providing a positive sense of wellbeing. Kyle, Mowen, and Tarrant (2004) analyse and subdivide the idea of 'sense of place' into four dimensions: place attachment, place identity, place dependence, and social bonding. This is particularly important for this study as it explores the diverse meanings that an individual experiences within a coastal neighbourhood environment.

However, few studies focus on the value of the sea and the coast as a therapeutic environment within a densely populated and built-up small island environment. This paper therefore aims to reveal three important aspects that are explored within a Maltese small island context:

- How important is the sea as a therapeutic landscape within a small island state, and what is its impact on health and wellbeing? 
- How beneficial is public accessibility to the coastal environment for deprived groups within society?

- How valuable are the coastal environment and the sea for people living in densely populated areas?

\section{Methodology}

The findings presented in this paper emerged as an incidental outcome from a wider study which explores how a deprived neighbourhood environment impacts on the health and wellbeing of inhabitants of Malta. Few studies analyse the role of the neighbourhood environment and its impact on health within a Mediterranean European context, and even fewer do so within a Maltese island context. Making use of grounded theory gave the possibility for participants to explain what is important to them and for their health and wellbeing.

Although at no point during the study were the respondents asked about the sea, the majority of participants felt the need to consider the role of the sea as important in their life and as contributing to their health and wellbeing. Therefore it was felt that the important therapeutic aspect of the sea and the coast as part of the neighbourhood environment and the way it impacts on health and wellbeing should not be disregarded. The respondents' narratives can contribute to understanding the importance of the sea within an island state context. In initial meetings, open-ended 'trigger questions' (Ochieng, 2010) prompted participants' views on topics such as household environment, family and child relations, education, and neighbourhood aspects that impact on health and wellbeing. The present paper thus explores to what extent respondents' views correspond with the theories of therapeutic landscapes reviewed above. The grounded theory approach also offers a way of reflecting upon and understanding the mutual and contingent actions that occur within specific contexts (Cope, 2009).

The three neighbourhoods under study were chosen since a relatively large proportion of the residents are dependent on social benefits when compared to the populations of other localities. The respondents were recruited through a national welfare agency. The reason behind choosing these three neighbourhoods was to explore how diverse neighbourhood contexts impact on the wellbeing of respondents in relation to culture, housing conditions and social processes.

One neighbourhood is the 'traditional town', which is a walled, densely built up, and densely populated town. This town hosts civic and administrative institutions, employing people of relatively affluent economic and social backgrounds. The coastline of this town is characterised by important harbours and rocky pocket beaches. The second neighbourhood is the 'deindustrialised town', which was prominent during the time when Malta was a sea base, both during the period of the Knights of St John (1500-1800) and during the British period (1800-1979) due to shipbuilding and ship repair industries. The coastline of the 'deindustrialised town' is characterised by a refurbished dock promenade, various pocket beaches, and rocky wave-cut platforms. The third neighbourhood is the 'modern town', which originally attracted residents as a booming touristic centre in Malta. However, many of the properties planned as summer residences are now permanent homes for families who cannot afford to live elsewhere. The coastline of the 'modern town' is characterised by rocky and sandy beaches and long promenades. The residents living in these three towns live at an approximate distance of 30 minutes' walk to the sea. 
A purposive sample of ten families, comprising parents, skipped-generation parents (grandparents), and their children were approached from each of the three study areas. The purposive sample was not intended to represent the wider population of the study area but was selected according to marital status and families with varying familial composition and all of whom were living in deprived neighbourhoods. Table 1 lists the respondents who narrated about their contact with the coast and the sea, using pseudonyms and non-identifiable information on each respondent. The degree of detail about the respondents is minimised to protect the identity of the informants. Ethical approval was given by the university to which the researcher was affiliated.

Table 1: List of pseudonyms of interviewees.

\begin{tabular}{|c|c|c|c|}
\hline Town & $\begin{array}{l}\text { Pseudonym of } \\
\text { parent/s, age }\end{array}$ & Marital status & $\begin{array}{l}\text { Connection to the coast and the } \\
\text { locality }\end{array}$ \\
\hline Traditional & Andrew (early 50s) & Cohabitant & Enjoys fishing, resident since birth \\
\hline Traditional & Luke (early 50s) & Married & Resident since birth \\
\hline Traditional & Charlene (early 40s) & Single mother & Resident since birth \\
\hline Traditional & Monica (late 40s) & Married & Resident since marriage \\
\hline Traditional & Joseph (early 60s) & $\begin{array}{l}\text { Skipped-generation } \\
\text { parent (grandparent) }\end{array}$ & Resident since birth \\
\hline Traditional & Maria (early 50s) & Married & Resident since birth \\
\hline Traditional & David (early 50s) & Married & Resident since birth \\
\hline Deindustrialised & Angela (early 30s) & Separated single mother & Resident since birth \\
\hline Deindustrialised & Michael (early 60s) & $\begin{array}{l}\text { Skipped-generation } \\
\text { parent (grandparent) }\end{array}$ & Resident since childhood \\
\hline Deindustrialised & Rose (early 60s) & $\begin{array}{l}\text { Skipped-generation } \\
\text { parent (grandparent) }\end{array}$ & Resident since birth \\
\hline Deindustrialised & Kenneth (early 40s) & Married & Resident since childhood \\
\hline Deindustrialised & Mark (late adolescence) & & Resident since birth \\
\hline Deindustrialised & Kyle (adolescent) & Rose's grandson & Resident since birth \\
\hline Modern & Nicole (late 40s) & Married & Resident more than 10 years \\
\hline Modern & Elise (early 40s) & Single mother & Resident less than 10 years \\
\hline Modern & Louise (early 50s) & Married & Resident since marriage \\
\hline Modern & Sarah (late 50s) & Married & Resident since marriage \\
\hline Modern & Claire (early 30s) & Separated single mother & Resident less than 10 years \\
\hline Modern & Kate (late childhood) & Louise's child & Resident since birth \\
\hline Modern & Jake (late childhood) & Sarah's child & Resident since birth \\
\hline
\end{tabular}

The verbatim interview transcripts were thematically analysed with the use of NVivo 10, which helped in storing and organising data. An open coding approach (Dey, 1999) was used to explore how the diverse blue coastal areas reflected personal therapeutic experiences and emotions and to group sentences and phrases under codes of themes and topics (Crang \& Cook, 2007; Bryman, 2008) related to therapeutic landscapes. Analysis of their narratives identified what were commonly seen as the most important aspects related to the sea as therapeutic landscapes and health and wellbeing.

The interviews were conducted throughout the year, during both summer and winter, and were conducted in coffee shops, public gardens, or the respondents' homes. Permission for interviews with written consent to conduct the interview was obtained from all participants. 
The length of these interviews ranged from one to three hours. The recorded interviews were conducted in the Maltese language and then translated to English. Children's, adolescents', adults', and elderly people's experiences by the sea were also included to better understand the experiences of the coastal environment across generations.

\section{Results and discussion}

Five overlapping dimensions of therapeutic experiences were identified from participants' narratives: symbolic, physical, social, temporal, and loss. The narratives are examined in this section in connection with the key theories explained above. An effort is made to analyse how the participants are experiencing the coastal environment within an island context and how these blue spaces enable them to experience positive health and wellbeing.

\section{Symbolic therapeutic experiences in different coastal areas}

Research in health geography analyses the restorative effects of water and how healing can occur within blue spaces due to encouraging physical activities, permitting encounters of socialisation and other therapeutic aspects beneficial for health and wellbeing (Kaplan \& Kaplan, 1989; Conradson, 2005; Foley, 2010). Water spaces emerge as areas where people experience leisure, exercise, and recovery (Andrews \& Kearns, 2005, Wylie, 2009) and are thus places where individuals can invest in their physical and mental health.

The respondents in this paper explained that since their neighbourhood is surrounded by the sea, the level of proximity enables them to experience the therapeutic value on a daily basis. Nicole explained that they feel extremely lucky in comparison to other Maltese inhabitants who live inland: "When I wake up, I drink my coffee while looking out at the sea." Luke points out that "When I get out of the house to go to work, the first thing I do is to peek at the sea. Sometimes it is rough. Sometimes calm." These narratives of the deprived inhabitants of a small island show the connection they feel with the sea and how their neighbourhood environment can provide them with a healthy sense of place (Gesler, 2003). The fact that, although they are deprived and live in one of the three neighbourhoods under study, the majority of the respondents can see the sea on a daily basis from the vicinity of their house is an indicator of general health and wellbeing and its therapeutic value, as recognised by Witten et al (2008). Lengen (2015) also explains that the human body experiences a 'feel-for-water' since there is an association with the blue shades of the sea, lakes, and rivers and improvements in mental health.

Living on a small island is further explained by Maria, who is thankful that the sea is not far away, as the increase in the built-up environment across the Maltese Archipelago limits the availability of open spaces: "There are so many cars and exhaust. Everywhere is built up. At least we have the sea that can compensate and give us a little dose of fresh air." Unlike in other international studies where the daily contact is predominantly within green landscapes (e.g. Milligan \& Bingley, 2007) and urban riverside spaces (Volker \& Kistemann, 2013), Malta is a small, densely populated island state with Mediterranean climatic conditions. The green environment is shrinking, and the inhabitants cannot enjoy the green therapeutic environment but only blue coastal spaces. Thus, within this small island context, daily contact with a therapeutic landscape (nature) is predominantly experienced through blue spaces rather than green spaces. The sea becomes the only accessible therapeutic landscape that can provide the 
daily dose of contact with nature. This thus calls for diverse and strict policies in coastal areas within small islands since this space is of great importance for the health and wellbeing of inhabitants, relative to those living on larger islands or mainland areas with available green spaces.

The contribution of the sea to individuals' health and wellbeing on a daily basis also emerges in large part because coastal areas across the Maltese Archipelago are public areas, free and openly accessible to all. Considering that all the respondents come from an economically deprived environment, the fact that they can enjoy access to the beach contributes greatly to their health and wellbeing. Louise explains that because she and her family live by the sea, they often feel as if they are on holiday: "You do not need a lot [of money] to prepare some sandwiches and go for a picnic in winter or for a swim in summer." None of the respondents expressed feelings or experiences of social exclusion near the coast as access to the beach is not considered a special privilege for the affluent or for important groups in society (Buzinde \& Yarnal, 2012). The idea of public access to therapeutic landscapes is not explored extensively in the literature within a Mediterranean context even though private beaches are on the rise in places such as Italy. Several studies that consider the context of private beaches look at coastal zone management of the beach itself (e.g. Marin, Palmisani, Ivaldi, Dursi, \& Fabiano, 2009), yet none of the studies analyse how the presence of private beaches impact on the wellbeing of inhabitants due to feelings of inequality.

This therefore draws attention to how important it is for deprived groups to experience therapeutic landscapes and how important it is to safeguard coastal spaces that are hotspots for development due to tourism. Within island contexts in particular, coastal spaces are highly important for the health and wellbeing of all communities, including the deprived.

However, although the beach is accessible to the public, several respondents referred to their preferred spots on the beach. These territorial spots, as explained by Charlene and Nicole, provide a sense of identity and place attachment, echoing findings in the literature (Eyles \& Williams, 2008; Kyle et al, 2004). Charlene feels an emotional attachment with a specific area on the beach: "I always swim here. This is where I belong. I never swim elsewhere." Reminiscent of Tuan's (1980) idea of rootedness to place, Nicole even states that some specific locations on the beach are considered as belonging to them: "I always put my bag here, and I always swim on this side of the beach. This is my area."

\section{Physical and mental health and wellbeing}

Water landscapes are increasingly considered as places that improve individuals' physical and mental health (Thomas, 2015). Townshend and Lake (2009) explain that green spaces (e.g. parks) and blue spaces (i.e. presence of water) in urban areas can motivate people to be physically active and provide restorative features that enhance health and wellbeing.

Respondents narrated that when they perform physical exercise near the sea, they enjoy the fresh air and feel renewed. This matches with Ryan's (2012) explanation that physical activity within a place is similar to an emotional transition. Monica explains that the daily physical activity by the coast gives her a positive emotional transition: "It is so enjoyable. We meet each other and walk every morning near the sea. It gives me energy and boosts me for the day." Furthermore, Sarah explains that her presence in the coastal environment stimulates her to be physically active: "I would not go to train in a gym, but I will not miss the walk near the sea." Therefore the sea helps people like Sarah contribute to their physical and mental health and helps them experience a 
feeling of closeness to nature and enjoy the beauty of the sea, enabling them to experience features of 'biophilia'. This is consistent with the research of Krenichyn (2006), who explains that exercise in green spaces is beneficial since it contributes more than a mere physical activity.

Apart from physical activity, Claire explains how the sea contributes to her mental health, as when she feels depressed, she goes out on the roof of her apartment and looks out at the wide open spaces of the sea, which helps her feel better. As noted by Tuan (1977), certain parts of a place may influence an individual's moods and emotions. Moreover, Volker and Kistemann (2010) analyse the idea of water as an element that can provide 'cleansing' and 'purifying'. Similarly, Angela and Maria narrate how the sea de-stresses them: "Instead of smoking or drinking, I go near the sea, and I feel better" (Angela). Indeed, aquatic elements are related to positive mood effects and are perceived as having restorative abilities (White et al, 2010).

Immersion in the water is another aspect expressed by respondents that contributes to their physical and mental health. Joseph explains the importance of swimming since he suffers from back pain, rheumatism, and arthritis: "When I swim all my aches and pains go away. I feel renewed. The sea is my only healer." Michael tries to swim all year round as he feels that it is highly beneficial for his health. Historically, swimming has been recognised as an activity with benefits for chronic diseases such as rheumatism, arthritis, and skin diseases (Foley, 2010).

Connected with the idea of immersion, some respondents even recount feelings of embodiment (Volker \& Kristemann, 2011; Foley, 2015). David narrates: "When I swim, my muscles relax, and the tensions in my body and mind are released in the wide expanse of water. You feel the water wrap around your body [...] It is a feeling that cannot be experienced elsewhere." Angela also explains: "When I walk into the sea, I start feeling the water rising up until my feet do not touch the bottom of the sea any longer. Then all my thoughts and concerns leave my mind. I concentrate on the water around me and on the movement of my body." This corresponds with the findings of Foley (2015) and Foley, Kearns, Kistemann, and Wheeler (2019), who maintain that a person experiences a number of benefits from the feeling of immersion in water, not only due to the physical movement but also due to the connection of the human body with the water elements. The narratives of Joseph, David, and Angela illustrate feelings of 'wholeness' and how restorative the elements of the sea can be to these respondents. This matches what Ryan (2012, p.73) explains as the "fullness of our bodily sensibilities."

\section{Social life}

Another emergent aspect that is important for the health and wellbeing of the respondents and that is connected with the coastal neighbourhood environment is how this open space provides individuals with experiences of social interaction, social bonding, and social cohesion in their community. Although all three neighbourhoods vary in their level of social processes and possibilities of forming features of social capital (Satariano \& Curtis, 2018), respondents from all the communities mention that the promenades or roads close to the sea provide opportunities for social interaction and socialisation. The coastal environment offers individuals with opportunities to encounter others and form social ties. Indeed, the majority of respondents describe how important the social relations that occur near the sea are for their health and wellbeing. "I always sit on this bench after mass, and I meet my relatives and friends, and we enjoy ourselves talking to each other near the sea" (Rose). Andrew also enjoys making new friends and values impromptu conversations when he is by the sea or when swimming: "You 
always meet someone whom you don't know. It is so interesting to make new friends and discuss different things." This is consistent with studies by Bell et al (2015), who indicate the importance of social relations and undemanding social interactions near the sea.

Respondents narrate how beneficial it is to meet other families by the sea. Elise explains that when her children "are playing in the water and on the sand with other children, they are developing" socially, physically, and cognitively (see also Piaget, 2007). Children too narrate that the time they spend by the sea both in summer and in winter is highly important for their health and wellbeing. Kyle narrates that the best leisure time is time spent at sea: "I enjoy diving with my friends, and I also enjoy playing with my younger sister on the sand." Jake says: "I love it when we race with our scooter or bicycle on the promenade [...] It is the place that is considered safe to play without the danger of cars" (Jake).

The coastal environment is thus beneficial for all age groups (elderly individuals, adults, and children) as it promotes family support and provides affordable opportunities for play, interaction, and relaxation, supporting the results of Ashbullby, Pahl, Webley, and White (2013).

These daily interactions near the sea between friends, relatives, and passers-by enable the respondents to enjoy positive and sometimes undemanding social interactions, which are highly important for health and wellbeing. "When you talk about your problems with families and friends, they are always ready to help and support you" (Monica). Individuals who spend time near the sea with friends and relatives buffer ill-health through feelings of bonding and social cohesion (Kawachi \& Berkman, 2001; Putnam, 2000; Satariano \& Curtis, 2018), while those who interact with passers-by may be buffering feelings of loneliness and also gain information and knowledge from resource-rich individuals (Bourdieu, 1986).

The proximity to the sea within an island is further accentuated by the importance of eating out by the sea. This activity enables the sharing of food and social interaction with others. David and Kenneth explain how the fact that they organise barbeques in summer near the sea enables them to better enjoy the benefits of social bonding and networks through sharing, entertainment, recreation, and socialisation. "The food that you eat near the sea always tastes better than at home" (Kate). These aspects also foster features of social capital, which can further buffer illhealth. However, one must also note that food cooked on barbeques near the sea might be likely to consist of processed meats accompanied by alcohol, which may contribute to ill health.

\section{Temporality}

Elements of temporality in relation to the coast also emerged as important for the respondents. The fact that the coastal environment is dynamic means that it is continuously attractive. Angela narrates her yearning to observe the sea and be in contact with the sea due to its dynamism: "I always stop here and take a photo of the sunrise. It is mesmerising [...] Sometimes the clouds are pink and lilac, sometimes white or grey. Sometimes there is a boat on the horizon [...] Sometimes I go again during the sunset, and the scenery is different but always beautiful and rewarding in diverse ways. It gives me energy." This supports the theory of Conradson (2005), who maintains that the meaning of a place varies between the individuals' experiences across different periods of time. It is also consistent with the idea of 'peak flow' (Csikszentmihalyi, 2002; Humberstone, 2013), in which some moments are experienced in such a rewarding enjoyable and motivating manner that they remain in the memory of the individual. 
Mark and Nicole appreciate the beauty of the sea across seasons. Nicole notes: "Sometimes after a storm, the beach changes and is filled with pebbles, and the sea is murky green, but it is still beautiful." While Mark recounts: "I am fascinated by the rolling waves as they break across the shore." Living close to the sea on an island gives respondents the possibility to continuously observe the sea's dynamism and appreciate its beauty in its different forms over time. This resonates with Conradson's $(2005,2007)$ explanation of "differential imbrications," where it is noted that the same place is perceived as therapeutic in different ways. Frequently observing the sea highlights one's appreciation of its dynamic tonality, shade, and colour. The importance of colour is emphasised by Elise, who describes how it is "transparent and beautiful with its green and blue colours. Sometimes it looks like the pictures on the magazines." Recent studies by Foley (2015), Doughty (2013), and Volker and Kristemann (2013) also explore the connection between colour, brightness, and blurred palette, which can also affect the therapeutic experience.

As in the study by Wood et al (2015), some respondents feel the need to show their connection with the coast and the sea by sharing nostalgic memories of the past. "I remember the lamp lighter coming with his ladder in the evening. It was so quiet that the only sound you could hear was the lapping of the sea across the shore" (Maria). Therefore the coastal environment and the sea are able to generate memories that the individuals experienced in the past. Blue spaces can enable positive emotions of nostalgia and attachment to place across one's life course (Casey, 2001; Budruk \& Stanis, 2013).

Part of the therapeutic experience is thus also connected with the cultural experience within the place (Gesler, 2003). Andrew narrates: "We used to dive for octopus and to collect clams. Those were the days." Research backs this argument that blue spaces can improve mental health since individuals can re-experience emotions and memories of their childhood by the sea (Coleman \& Kearns, 2015; Lengen, 2015). This further emphasises the important therapeutic cultural connections islanders have with the sea and how it impacts on their health and wellbeing as they feel a deep connection with the sea's role in food provision, contact with nature, and nostalgic memories, which also help develop the islander's identity and culture.

Feelings of loss

Although the narratives regarding the connection with the sea were predominantly positive, some respondents express fear related to the loss of land, ecosystems, and coastal environment related to climate change, pollution, and sea level rise. Wood et al (2015) refer to 'solastalgia', defined by Albrecht et al (2007) as an emotional environmental loss, which can negatively impact on health and wellbeing. When one lives on an island, this feeling of loss may be more pronounced.

Some respondents feel that human intervention has destroyed some of the coastal environments that were enjoyable and therapeutic for them. This is connected to what Kearns and Collins (2012) explain as 'lived space', stating that a relationship that had been built between people and place is being lost. Joseph recounts: "We used to swim there, it used to be full of sand. Now it is all gone [...] And here, we used to jump into the sea and have fun with our friends, and now it is part of the hotel." Andrew explains that the fish catches have declined and that, due to plastic in the sea, fish are no longer a healthy meal: "Only the memories remain. Now there aren't any [fish] left or they are all full of plastic" (Andrew). Similarly, Elise is scared that climate change and sea level rise will cause the coast to be lost and that nothing can be done 
to reverse this damage: "I am afraid that one day I will wake up to find that the beach is gone and all here is submerged. Then it will be too late to take action!"

Maria is also afraid that the coast will continue to deteriorate due to the increase in development and factors related to climate change. She explains that the present population needs to preserve the coastal environment for future generations and their need to enjoy it too: "How sorry I feel for my children and grandchildren if here will be built up with flats and hotels, because they can never enjoy what I enjoyed by the sea." These narratives demonstrate the emotional attachment that respondents have formed with the coast and the sea. The pressure of land scarcity is higher when one lives on a small island, and when land is taken away for residential and tourism purposes, respondents feel that the memories they have formed within these coastal spaces are lost. This is damaging for their health and wellbeing.

This highlights the need to preserve and protect coastal environments, which are truly important for the Maltese population. Following the collapse of a natural arch at Dwejra Bay (Azure Window) due to a storm, people reacted in diverse ways towards this landform loss (Satariano \& Gauci, 2019). Several Maltese inhabitants felt that part of their identity was lost and were disappointed that coming generations would be unable to enjoy the same experiences they had when the arch was still standing. This aspect of loss should contribute to the literature of emotional geographies as health and wellbeing are adversely affected when there is fear of loss of a place that provides emotional attachment.

Loss of biodiversity due to overfishing, loss of land due to the importance granted to the economy and tourism, loss of therapeutic landscapes, and fear of sea level rise are significant for the respondents. This suggests that the relational approach analysed within the therapeutic landscape theory emphasised by Conradson (2005) should also consider the aspect of loss and fear of loss as well as the idea that a landscape that is therapeutic might not be permanent due to natural changes or human intervention. The idea that the coast-once accessible to all-might one day be lost is alarming for people living on a small island.

\section{Conclusion}

This helps fill a gap in the literature by analysing the important therapeutic role that the coastal environment plays for deprived inhabitants within the small island state of Malta. Although there has been an increase in research on the beneficial, therapeutic role of the sea on people's health and wellbeing, few studies (an exception is Kearns \& Collins, 2012) consider the concept of therapeutic landscapes within a small island context. The islanders' narratives have depicted diverse attributes of the coastal landscape and proximity to the sea contribute to their health and wellbeing. Moreover, within a small island context, land use may be denser, thereby limiting the availability of open spaces and enhancing the value of coastal environments.

It also emerged how important the sea is for deprived groups in particular, with spending time by the sea serving as a holiday that they can afford. Indeed, Curtis (2004, p.50) points out that "Access to therapeutic landscapes for people whose social position or cultural affiliation causes them to feel undervalued or excluded in wider society may help to reduce health inequalities." Moreover, the sea provides opportunities for socialisation, enabling interactions between different groups of people from different socio-economic circumstances, which may in turn buffer ill health. There is a need for further research on the salutogenic effects that 
therapeutic landscapes can have on deprived individuals when spending time in accessible, free, and public therapeutic landscapes and how this impacts positively on health and wellbeing.

Another aspect to which this paper contributes is the connection that people from different age groups and generations have with the sea and how much this impacts positively on their health and wellbeing. Similar to studies by Bell et al (2015) and Smaldone et al (2005) show how social interaction in public spaces enhances the opportunities for positive experiences in these coastal therapeutic landscapes. The coast as a public space becomes a meaningful 'container' for important social relationships of bonding, experiences of reciprocity, nostalgia, and shared experiences.

The dynamism of the sea also generates memories of the past among older inhabitants, yet feelings of solastalgia (Albrecht et al, 2007) are also experienced with the increase in coastal development. This may be more pronounced on a densely populated small island where land is scarce. When losing land to development or to the effects of climate change, inhabitants experience loss of identity, loss of attachment to place, and loss of the therapeutic elements experienced on a daily basis. Fear of loss clearly emerged in relation to the theory of therapeutic landscapes, which highlights the necessity of further examining this aspect in future research studies in order to better understand how this impacts individuals' health and wellbeing.

Reflecting on the United Nations' Agenda 21 (United Nations, 1992), it is vital that government authorities recognise the therapeutic elements of coastal environments on small islands as well as their importance for health and wellbeing by improving the environmental quality and by directing policies for the protection of these spaces in order to safeguard and promote the health and wellbeing of all inhabitants (World Health Organization, 1993).

\section{References}

Aggleton, P. (1990). Health. London: Routledge. https://doi.org/10.4324/9780203449912

Albrecht, G., Sartore, G. M., Connor, L. Higginbotham, N., Freeman, S., Kelly, B., Stain, H., Tonna, A., \& Pollard, G. (2007). Solastalgia: the distress caused by environmental change. Australas Psych, 15(1), 95-98. https://doi.org/10.1080/10398560701701288

Andrews, G. J., \& Kearns, R. A. (2005). Every day health histories and the making of place: The case of an English coastal town. Social Science \& Medicine, 60, 2697-2713. https://doi.org/10.1016/j.socscimed.2004.11.004

Ashbullby, K., Pahl, S., Webley, P., \& White, M. (2013). The beach as a settling for families' health promotion: A qualitative study with parents and children living in coastal regions in Southwest England. Health Place, 23, 138-147. https://doi.org/10.1016/j.healthplace.2013.06.005

Bell, S. L., Foley, R., Houghton, F. Maddrell, A., \& Williams, A. (2018). From therapeutic landscapes to healthy spaces, places and practices: A scoping review, Social Science $\mathcal{E}$ Medicine, 196, 123-130. https://doi.org/10.1016/j.socscimed.2017.11.035

Bell, S., Phoenix, C., Lovell, R., \& Wheeler, B. (2015). Using GPS and geo-narratives: A methodological approach for understanding and situating everyday green space encounters. Area, 47(1), 88-96. https://doi.org/10.1111/area.12152 
Bossevain, J. (1996). Rituals, tourism and cultural commoditization in Malta: Culture by the Pound? In T. Selwyn (ed). The tourist image: Myths and myth making in tourism (pp. 105120). Chichester \& New York: Wiley.

Bourdieu, P. (1986). Distinction: A social critique of the judgement of taste. London: Routledge.

Braudel, F. (1972). The Mediterranean and the Mediterranean world in the Age of Philip II. London: The Folio Society.

Brody, A. J. (1998). 'Each man cried out to his God': The specialised Religion of Canaanite and Phoenician sea farers. Atlanta: Scholars Press.

Bryman, A. (2008). Social research methods (3 ${ }^{\text {rd }}$ ed.). New York: Oxford University Press. https://doi.org/10.1080/13645570701401644

Budruk, M., \& Wilhelm Stanis, S. (2013). Place attachment and recreation experience preference: A further exploration of the relationship. Journal of Outdoor Recreation and Tourism, 1-2, 51-61. https://doi.org/10.1016/j.jort.2013.04.001

Buzinde, C., \& Yarnal, C. (2012). Therapeutic landscapes and postcolonial history: A theoretical approach to medical tourism, Social Science \& Medicine, 74, 783-787. https://doi.org/10.1016/j.socscimed.2011.11.016

Casey, E. (2001). Between geography and philosophy: What does it mean to be in the PlaceWorld. Annals of the Association of American Geographers, 91(4), 683-693. https://doi.org/10.1111/0004-5608.00266

Coleman, T., \& Kearns, R. (2015). The role of blue spaces in experiencing place, aging and wellbeing: Insights from Waiheke Island, New Zealand. Health Place, 35, 206-217. https://doi.org/10.1016/j.healthplace.2014.09.016

Conradson, D. (2005). Landscape, care and the relational self-therapeutic-counters in rural England. Health Place, 11, 337-378. https://doi.org/10.1016/j.healthplace.2005.02.004

Conradson, D. (2007). The experiential economy of stillness: Places of retreat in contemporary Britain. In A. Williams (ed.). Therapeutic Landscapes (pp. 33-48). Farnham: Ashgate. https://doi.org/10.4324/9781315551166-3

Cope, M. (2009). Grounded theory. In: R. Kitchin \& N. Thrift (eds.). International encyclopedia of human geography (pp. 647-650). Oxford: Elsevier. https://doi.org/10.1016/B978$\underline{008044910-4.00450-8}$

Crang, M., \& Cook, I. (2007). Doing ethnographies. London: Sage. https://doi.org/10.4135/9781849208949

Csikszentmihalyi, M. (2002). Flow. London: Rider.

Curtis, S. (2004). Health and inequality: Geographical perspectives. Thousand Oaks, CA: Sage. https://doi.org/10.4135/9781849209243

Curtis, S. (2010). Space, place and mental health. Farnham: Ashgate.

Dey, I. (1999). Grounding grounded theory: Guidelines for qualitative inquiry. San Diego: Academic Press. https://doi.org/10.1016/B978-012214640-4/50011-5

Doughty, K. (2013). Walking together: The embodied and mobile production of a therapeutic landscape. Health Place, 24, 140-146. https://doi.org/10.1016/j.healthplace.2013.08.009

Dubos, R. (1987). Mirage of health: Utopias, progress, and biological change. New Brunswick: Rutgers University Press. 
Ducrotoy, J. P., \& Furukawa, K. (2009). Integrated coastal management: Lessons learned to address new challenges. Marine Pollution Bulletin, 102, 241-242. https://doi.org/10.1016/j.marpolbul.2016.02.059

Eyles, J., \& Williams, A. (2008). Sense of place, health and quality of life. Farnham: Ashgate.

Foley, R., Kearns, R., Kistemann, T., \& Wheeler, B. (2019). Blue space, health and wellbeing: Hydrophilia unbounded. London \& New York: Routledge. https://doi.org/10.4324/9780815359159

Foley, R., \& Kistemann, T. (2015). Blue space geographies: enabling health in place. Health Place, 35, 157-165. https://doi.org/10.1016/j.healthplace.2015.07.003

Foley, R. (2010). Healing waters: Therapeutic landscapes in historic and contemporary Ireland. Aldershot: Ashgate.

Foley, R. (2015). Swimming in Ireland: Immersions in therapeutic blue space. Health Place, 35, 218-225. https://doi.org/10.1016/j.healthplace.2014.09.015

Fontenay, M. (1988). La place de la course dans l'économie portuaire: l'example de Malte et des ports barbaresques, Annales, 43(6). https://doi.org/10.3406/ahess.1988.283560

Gesler, W. (1992). Therapeutic landscapes: Medical issues in light of the new cultural geography. Soc. Sci. Med., 34, 735-746. https://doi.org/10.1016/0277-9536(92)90360-3

Gesler, W. (2003). Healing Places. Lanham: Rowman \& Littlefield.

Gesler, W. M., (1996). Lourdes: Healing in a place of Pilgrimage. Health Place, 2, 95-105. https://doi.org/10.1016/1353-8292(96)00004-4

Humberstone, B. (2013). Adventurous activities, embodiment and nature, spiritual, sensual and sustainable? Embodying environmental justice. Motriz, 19, 565-571. https://doi.org/10.1590/S1980-65742013000300006

Huntingford, E., \& Turner, A. (2011). Trace metals in harbour and slipway sediments from the island of Malta, Central Mediterranean. Marine Pollution Bulletin, 62, 1557-1561. https://doi.org/10.1016/j.marpolbul.2011.05.015

Kaplan, R., \& Kaplan, S. (1989). The experience of nature: A psychological perspective. New York: Cambridge University Press.

Kawachi, I., \& Berkman, L. F. (2000). Social cohesion, social capital and health. In L. F. Berkman \& I. Kawachi (eds.). Social epidemiology (pp. 178-190). New York: Oxford University Press.

Kearns, R., \& Collins, D. (2012). Feeling for the coast: The place of emotion in resistance to residential development. Social \& Cultural Geography, 13, 937-955. https://doi.org/10.1080/14649365.2012.730150

Kearns, R., \& Collins, D. (2000). New Zealand children's health camps: Therapeutic landscapes meet the contract state. Social Science \& Medicine, 51, 1047-1059. https://doi.org/10.1016/S0277-9536(00)00020-4

Krenichyn, K. (2006). 'The only place to go and be in the city': Women talk about exercise, being outdoors and the meaning of a large urban park. Health Place, 12, 631-643. https://doi.org/10.1016/j.healthplace.2005.08.015

Kyle, G., Mowen, A., \& Tarrant, M. (2004). Linking place preferences with place meaning: An examination of the relationship between place motivation and place attachment. $J$. Environ. Psychol., 24, 439-454.

Laverack, G. (2004). Health promotion practice: Power and empowerment. London: Sage. 
Lengen, C. (2015). The effects of colours, shapes and boundaries of landscapes on perception, emotion and mentalising processes promoting health and wellbeing. Health Place, 35, 166177. https://doi.org/10.1016/j.healthplace.2015.05.016

Maas, J., Verheij, R. A., Groenewegen, P. P., deVries, S., \& Spreeuwenberg, P. (2006). Green space, urbanity and health: How strong is the relation?. Journal of Epidemiology and Community Health, 60, 587-592. https://doi.org/10.1136/jech.2005.043125

Mallia-Milanes, V. (1978). Towards an economic history of eighteenth century Malta: Buzzaccarini Conzaga's correspondence to the Venetian magistracy of trade, 1754-1776. Hyphen, 2, 1-25.

Marin, V., Palmisani, F., Ivaldi, R., Dursi, R., \& Fabiano, M. (2011). Users' perception analysis for sustainable beach management in Italy. Ocean and Coastal Management, 54, 821-830. https://doi.org/10.1016/j.ocecoaman.2011.09.004

McKinley, E., \& Acott, T. (2018). Coastal communities: The missing link in marine policy? Marine Policy, 97, 220-222. https://doi.org/10.1016/j.marpol.2018.07.005

Milligan, C., \& Bingley, A. (2007). Restorative places or scary spaces? The impact of woodland on mental wellbeing of young adults. Health Place, 13, 799-811. https://doi.org/10.1016/j.healthplace.2007.01.005

Morton, J. (2001). The role of the physical environment in Ancient Greek sea faring. Leiden: Brill. https://doi.org/10.1163/9789004351073003

Muscat, J. (2002). Maritime history of Malta. Heritage, 87, 1736-1739.

Nichols, W. J. (2014). Blue mind: The surprising science that shows how being near, in, on, or under water can make you happier, healthier, more connected and better at what you do. New York City: Back Bay Books.

Ochieng, B. (2010). You know what I mean: The ethical and methodological dilemma and challenges for Black researchers interviewing Black families. Qualitative Health Research, 20, 1725-1735. https://doi.org/10.1177/1049732310381085

Piaget, J. (2007). The child's conception of the world: A 20th century classic of child psychology. (2 $2^{\text {nd }}$ ed.). Lanham: Rowman \& Littlefield.

Putnam, R. D. (2000). Bowling alone: The collapse and revival of American community. New York \& London: Simon \& Schuster. https://doi.org/10.1145/358916.361990

Reid, L., \& Hunter, C. (2011). Personal wellbeing and interactions with nature. BeWEL State of Understanding Report, 1. Swindon: ESRC.

Ryan, A. (2012). Where land meets sea: Coastal explorations of landscape, representation and spatial experience. Surrey: Ashgate.

Satariano, B., \& Curtis, S. E. (2018). The experience of social determinants of health within a Southern European Maltese culture. Health Place, 51, 45-51. https://doi.org/10.1016/j.healthplace.2018.02.011

Satariano, B., \& Gauci, R. (2019). Landform loss and its effect on health and well-being: The collapse of the Azure Window (Gozo) and the resultant reactions of the media and the Maltese community. In R. Gauci \& J. A. Schembri (eds.). Landscapes and landforms of the Maltese Islands. Cham: Springer. https://doi.org/10.1007/978-3-030-15456-1 23

Smaldone, D., Harris, C., \& Sanyal, N. (2005). An exploration of place as a process: The case of Jackson Hole, WY. Journal of Environmental Psychology., 25, 397-414. 
Thomas, F. (2015). The role of natural environments within women's everyday health and wellbeing in Copenhagen, Denmark. Health Place, 35, 187-195. https://doi.org/10.1016/j.healthplace.2014.11.005

Townshend, T., \& Lake, A. A. (2009). Obesogenic urban form: Theory, policy and practice. Health Place, 15, 909-916. https://doi.org/10.1016/j.healthplace.2008.12.002

Tuan, Y. F. (1980). Rootedness versus sense of place. Landscape, 24, 3-8.

Tuan, Y. F. (1977). Space and place: The perspective of experience. Minneapolis: University of Minnesota Press.

Tuan, Y. F. (1974). Topophilia. New York: Columbia University Press.

United Nations (1992). AGENDA 21. Adopted at the UN Conference on Environment and Development, Rio De Janeiro, 3-14 June1992.

Vella, N. C. (2002). The lie of the land: Ptolemy's Temple of Hercules in Malta. Ancient Near Eastern Studies, 29, 83-112. https://doi.org/10.2143/ANES.39.0.501776

Völker, S., \& Kistemann, T. (2013). “I'm always entirely happy when I'm here!” Urban blue enhancing human health and well-being in Cologne and Düsseldorf, Germany. Social Science \& Medicine, 78,113-124. https://doi.org/10.1016/j.socscimed.2012.09.047

Völker, S., \& Kistemann, T. (2011). The impact of blue space on human health and wellbeing: Salutogenetic health effects of inland surface waters: A review. International Journal of Hygiene and Environmental Heath, 214, 449-460. https://doi.org/10.1016/j.ijheh.2011.05.001

White, M., Smith, A., Humphreys, K., Pahl, S., Snelling, D., \& Depledge, M. (2010). Blue space: The importance of water for preference, affect, and restorativeness ratings of natural and built scenes. Journal of Environmental Psychology, 30, 482-493. https://doi.org/10.1016/j.jenvp.2010.04.004

World Health Organization (1993). Health for all Targets. The Health Policy for Europe. European Health for all Series No.4. WHO Regional Office for Europe. Copenhagen.

World Health Organization (1948). Constitution of the WHO. Geneva: WHO.

Witten, K., Hiscock, R., Peace, J., \& Blakely, T. (2008). Neighbourhood access to open spaces and the physical activity of residents: a national study. Preventative Medicine, 47, 299-303. https://doi.org/10.1016/j.ypmed.2008.04.010

Wood, V. J., Gesler, W., Curtis, S. E., Spencer, I. H., Close, H. J., Mason, J., \& Reilly, J. G. (2015). Therapeutic landscapes and the importance of nostalgia, solastalgia, salvage and abandonment for psychiatric hospital design. Health Place, 33, 83-89. https://doi.org/10.1016/j.healthplace.2015.02.010

Wylie, J. W. (2009). Landscape, absence and the geographies of love. TIBG, 34(,3),275-289. https://doi.org/10.1111/j.1475-5661.2009.00351.x

Zarb, J. (2004). L-istorja tat-turizmu f Malta u Ghawdex. Malta: BDL. 